\title{
Tiotropium improved lung function more than ipratropium in chronic obstructive pulmonary disease
}

van Noord JA, Bantje Th A, Eland ME, et al, on behalf of the Dutch Tiotropium Study Group. A randomised controlled comparison of tiotropium and ipratropium in the treatment of chronic obstructive pulmonary disease. Thorax 2000 Apr;55:289-94.

Source of funding: Boehringer Ingelheim $B V$.

For correspondence: Dr J A van Noord, Department of Respiratory Diseases, Atrium Medisch Centrum, Henri Dunantstraat 5, 6419 PC Heerlen, the Netherlands. Fax +31 455767534 .
Randomised \{allocation concealed*\}†, blinded (patient and outcome assessor),* controlled trial with 13 weeks of follow up.

\section{Setting}

14 centres in the Netherlands.

\section{Patients}

288 patients $\geqslant 40$ years of age (mean age $64 \mathrm{y}, 83 \%$ men) who were current or past smokers with a diagnosis of COPD and stable airways obstruction, an $\mathrm{FEV}_{1}<65 \%$ of the predicted normal rate, and a ratio of $\mathrm{FEV}_{1}$ to forced vital capacity (FVC) of $<70 \%$. Exclusion criteria included a history of asthma, allergic rhinitis, or atopy; a recent history of myocardial infarction, heart failure, or cardiac arrhythmia requiring drug treatment; upper respiratory tract infection in the past 6 weeks; and hypersensitivity to anticholinergic drugs. 90\% completed all tests.

\section{Intervention}

191 patients were assigned to tiotropium, $18 \mu \mathrm{g}$ once daily, delivered by a dry powder inhaler system; and 97 were assigned to ipratropium, $40 \mu \mathrm{g} 4$ times daily, delivered by a metred dose inhaler. Each group also received placebo doses of the other treatment.

\section{Main outcome measures}

Lung function, peak expiratory flow (PEF), use of concomitant salbutamol, and adverse effects.

\section{Main results}

Trough, peak, and mean $\mathrm{FEV}_{1}$ response and trough and mean FVC response showed greater improvement with tiotropium than with ipratropium (table). Morning and evening PEF was consistently better with tiotropium $(p<0.05)$. Use of concomitant salbutamol was lower in the tiotropium group $(\mathrm{p}<0.05)$. The groups did not differ for adverse effects.

\section{Conclusions}

In patients with chronic obstructive pulmonary disease, tiotropium improved lung function more than ipratropium. The safety profiles of the 2 drugs were similar.
*See glossary.

$\dagger$ Information provided by the author.

Tiotropium v ipratropium at 13 weeks in chronic obstructive pulmonary disease (lung function improvement, in litres, compared with baseline at start of study)

\begin{tabular}{llll} 
Outcomes & Tiotropium & Ipratropium & Mean difference $(95 \%$ CI) \\
FEV $_{1}$ trough & 0.16 & 0.03 & $0.13(0.08$ to 0.18$)$ \\
\hline FEV $_{1}$ peak (at $\left.50 \mathrm{~d}\right)$ & 0.38 & 0.30 & $0.08(0.02$ to 0.15$)$ \\
\hline FEV $_{1}$ mean (over 6 h) & 0.26 & 0.18 & $0.08(0.03$ to 0.13$)$ \\
\hline FVC trough & 0.39 & 0.18 & $0.21(0.10$ to 0.32$)$ \\
\hline FVC mean (at 50 d) & 0.62 & 0.45 & $0.17(0.50$ to 0.29$)$
\end{tabular}

fFVC=forced vital capacity.

\section{COMMENTARY}

The anticholinergic agent ipratropium bromide is frontline treatment for patients with non-asthmatic COPD. ${ }^{1}$ In most of these patients, ipratropium used alone is more effective as a bronchodilator than is an inhaled $\beta$-agonist used alone. (Combination therapy, however, is often more effective than either agent used alone.) Ipratropium bromide has a relatively short duration of action, requiring inhalation every 6 to 8 hours. In addition, ipratropium non-selectively inhibits all 3 of the known muscarinic receptors in the human airway $\left(\mathrm{M}_{1}, \mathrm{M}_{2}\right.$, and $\left.\mathrm{M}_{3}\right)$. This is of theoretical concern because the $\mathrm{M}_{2}$ receptor normally acts as a feedback inhibitory receptor; blockade of the $\mathrm{M}_{2}$ receptor results in increased acetylcholine release in the airway and could attenuate or reverse the bronchodilation achieved by blockade of the $\mathrm{M}_{1}$ and $\mathrm{M}_{3}$ receptors. ${ }^{2}$ The clinical relevance of this issue is uncertain.

Tiotropium is a potent and long lasting muscarinic antagonist that has "kinetic selectivity" for $\mathrm{M}_{1}$ and $\mathrm{M}_{3}$ receptors over $\mathrm{M}_{2}$ receptors. ${ }^{2}$ A single dose of inhaled tiotropium produces bronchodilation for 24 hours in patients with COPD ${ }^{3}$ and attenuates methacholine induced bronchoconstriction for 48 hours in patients with asthma. ${ }^{4}$ Once daily dosing for 4 weeks in stable patients with COPD provides sustained bronchodilation with an excellent safety profile.

The study by van Noord et al provides important data, showing the superiority of tiotropium $(18 \mu \mathrm{g}$ once/d) over the usual dose of ipratropium $(40 \mu \mathrm{g} 4$ times/d). Patients were permitted to use many of their own usual medications (including methylxanthines, inhaled steroids, and oral steroids up to $10 \mathrm{mg}$ of prednisone/d) during the course of the trial, showing the effectiveness of tiotropium in a meaningful clinical context. Tiotropium, not yet approved for use in the United States, appears to have great potential in the long term maintenance treatment of COPD.

Herbert P Wiedemann, MD Cleveland Clinic Foundation Cleveland, Ohio, USA

1 American Thoracic Society. Am J Respir Crit Care Med 1995;152:S77-121.

2 Barnes PJ. Chest 2000;117:S63-6.

3 Maesen FP, Smeets JJ, Sledsens TJ, et al. Dutch Study Group. Eur Respir J 1995;8:1506-13. O'Connor BJ, Towse LJ, Barnes PJ. Am J Respir Crit Care Med 1996;154:876-80.

Littner MR, Ilowite JS, Tashkin DP, et al. Am J Respir Crit Care Med 2000;161:1136-42. 